\title{
Validation of the Alcohol Use Disorders Identification Test (AUDIT) - Dusun Version in Alcohol Users in Sabahan Borneo
}

\author{
Nicholas Pang ${ }^{1}$, Gloria Lee ${ }^{1}$, Matthias Tseu ${ }^{1}$, Jane Ivana Joss ${ }^{1}$, \\ Helda Artika Honey ${ }^{1}$, Wendy Shoesmith ${ }^{1}$, Sandi James², \\ Jiann Lin Loo ${ }^{1}$, Helen Lasimbang ${ }^{1}$ \\ ${ }^{1}$ Faculty of Medicine and Health Sciences Universiti Malaysia, Sabah, ${ }^{2}$ La Trobe University, \\ Melbourne Victoria, Australia
}

\begin{abstract}
Introduction: The Alcohol Use Disorder Identification Test (AUDIT) developed by WHO is instrumental in identifying individuals on the alcohol misuse spectrum. However there is no culturally appropriate Dusun language version in Sabahan Borneo. This study aims to develop and validate a Dusun language version of AUDIT (AUDIT-D). Methods: AUDIT was translated to Dusun and back translated to English and Malay. The first version was pilot tested in 20 participants and harmonised. The harmonised version was administered to 50 Dusun first language speakers fluent in Malay from villages in rural Sabah. Participants filled in socio-demographic questionnaires, Dusun (AUDIT-D) and Bahasa Malaysia (AUDIT-M) versions of AUDIT, and validated Bahasa Malaysia versions of the M.I.N.I. alcohol dependence subscale and CAGE. Results: ROC curves calculated AUDIT-D dependence cut-off of 9 and more, with prevalence of dependence at $46 \%$. Factor analysis of AUDIT-D yielded a one- or three-factor solution, distinct from the AUDIT-M factor structure. Cronbach alpha coefficients for the total AUDIT-D was 0.83. Significant Spearman's correlations existed between AUDIT-D and AUDIT-M scores (Spearman's rho=0.999, p<.001). AUDIT-D and AUDIT-M were both significantly correlated with M.I.N.I. alcohol dependence subscales ( $r h o=0.624$ and 0.617 respectively, with $p<0.0001$ ). Both were not significantly correlated with CAGE. Conclusion: The AUDIT-D questionnaire has acceptable psychometric properties, properties and demonstrates similar factor structures to other areas with high alcohol dependence prevalence. It is suitable for the assessment and identification of alcohol use disorders in the unique Sabahan Borneo cultural landscape.
\end{abstract}

Keywords: AUDIT, alcohol, Dusun, M.I.N.I.

Copyright (C) 2020 KBCSM, Zagreb

e-mail: alcoholism.kbcsm@gmail.com•www.http://apr.kbcsm.hr

Correspondence to:

Nicholas Pang' Faculty of Medicine and Health

Sciences Universiti Malaysia, Sabah

E-mail: nicholas@ums.edu.my

\section{Introduction}

The Alcohol Use Disorder Identification Test (AUDIT) developed by the WHO is designed to identify individuals along the full spectrum of alcohol misuse [1]. The AUDIT has proven to be an effective diagnostic in- 
strument comparable to other well-known alcohol screening tools such as the CAGE Assessment for Alcohol Abuse (CAGE) and the Michigan Alcoholism Screening Test (MAST) [2]. Both the latter scales have their limitations, as the CAGE cannot differentiate between alcohol abuse and dependence [3]. The MAST is lengthy with 24 questions which is a challenge to administer in a busy clinical setting [4].

In the Malaysian setting, a Malay language AUDIT (AUDIT-M) was validated in 2015 [5]. It has subsequently been adopted widely by various state department public health and non-communicable disease units in doing universal screening for alcohol use disorders. However, Malaysia is a tale of two regions - the Peninsular Malaysian alcohol use patterns diverge greatly from that of the Borneo states, Sabah and Sarawak [6]. This is because traditional alcohol production and consumption is inextricably interwoven into Bornean culture [7], and hence there are strong positive as well as negative connotations associated with alcohol use and misuse [8].

Sabah, in particular, is one of the three areas in Malaysia with the highest level of alcohol consumption in Malaysia [9]. In Sabah state, alcohol misuse is especially prevalent in the majority Kadazandusun ethnic community [7]. It has been directly or indirectly implicated in domestic violence, absenteeism from employment, and is linked to physical injuries and motor vehicle accidents [10]. However, due to the perennial conflict between tradition and intoxication, people may be wary of revealing their alcohol use issues to third parties. Hence there is an urgent need to boost AUDIT screening in order to increase identification of alcohol use disorders in ethnic communities in a culturally sensitive manner, in order to increase provision of relevant services, targeted interventions, and public health measures in the areas that need it most.

However, for many Kadazandusun people, especially those in rural areas, they are only fluent in Dusun, a language linguistically distinct from the national Malay language. It is the most widely spoken ethnic language in Sabah Borneo, with an estimated 141,000 speakers [11]. There is so far no translated or validated research or clinical questionnaire in the Dusun language (be it for alcohol use or for other substances) that would allow identification of affected individuals. This is a major barrier to alcohol screening and counselling programmes. No doubt a large proportion of Dusun-speaking individuals are fluent in Malay due to universal basic education up to secondary school level in Malaysia.

However, quantitative surveys suggest Dusun people are more comfortable and willing to open up when approached in their native language, and are more likely to warm up to researchers - and hence clinicians and public health interventions - if a native language screening or intervention is offered in any little way [7]. Hence, once validated, the questionnaire will fill an urgent gap in the system, providing a valuable tool for early detection of alcohol abuse among the Kadazandusun language speaking population. This is also a vital step in breaking barriers to redress health iniquity and imbalances in healthcare amongst indigenous and rural groups. Availability of English and Malay language AUDIT scales alone will only serve the self-fulfilling prophecy of concentrating alcohol prevention efforts in more affluent, educated, and urbanised parts of Malaysia, continuing to widen the treatment gap between rural Dusun-speaking Borneans and their West Malaysian counterparts.

Pang, Lee, Tseu, Joss, Honey, Shoesmith, James, Loo, Lasimbang 
Further compounding the matter, there are currently no tools available for mental health related issues that are available in any Sabahan native languages. Alcohol use is generally the "tip of an iceberg" of psychological issues or diagnosable mental health disorders [12], and having culturally sensitive conversations about alcohol is potentially an effective opening gambit in identifying other comorbid mental health issues. Hence, having a Dusun-validated AUDIT (AUDIT-D), and consequently being able to identify an alcohol use disorder in a distressed individual, can literally be the key to tapping into the unexplored but no doubt staggering mental health issue burden in the ethnic Sabah population, which was estimated to be $42.7 \%$ in the recent National Health and Morbidity Survey [13]. Dusun language validation was performed first, as it has a larger catchment area and population of speakers, and there are more healthcare workers from the Dusun community. A successful AUDIT$\mathrm{D}$ validation would then expedite efforts to further validate the scale into other native languages where alcohol use represents a major public health problem.

\section{Methods}

Permission to translate the questionnaire was obtained from the original authors [1]. The study was conducted in 3 stages based on WHO instrument validation and translation guidelines [14]:

Stage 1: Two bilingual nursing students translated the AUDIT, with reference as well to the validated Malay version of AUDIT (AUDIT-M) [5] into a Kadazan-Dusun version (AUDIT-D). The two nursing students assessed the semantic equivalence of all 10 items of the scale between Malay and Dusun. It was impossible to perform a direct English to Dusun translation without reference to the
AUDIT-M, as it was difficult to find a native speaker of the target language (Dusun) who had the requisite near-native proficiency in English as well. We then got two fluent speakers of Malay and English who also have Dusun proficiency, both of whom were specialists and university lecturers, to back translate it into both Malay and English. Inconsistencies between the forward and back translations were subsequently ironed out with the assistance of all 4 translators through a committee. This process yielded the harmonized translation.

Stage 2: Pilot testing was performed with 20 Dusun native speakers from a Dusun speaking village, who confirmed the lexicon employed by the AUDIT-D translation was mutually intelligible with what they understood. Any unsuitable words or language identified by the respondents were noted and corrected. This process yielded a final translated version of the AUDIT-D.

Stage 3. The final translated version of AUDIT-D was administered in a validation study design. A sample of 50 individuals was used as the AUDIT-D contains 10 items, hence 50 was the minimum sample size statistically significant, using a ratio of 1 item:5 respondents. We then ran the AUDIT-D with a mix of villagers from a Dusun speaking village, Dusun speaking university students, and Dusun speaking members of the public.

Patients were approached by the research team to take part in the study and provided written informed consent for participation. The inclusion criteria was as follows:

- Above 18 years of age.

- Alcohol consumers, irrespective of volume.

- Willing to participate in the study.

- Able to read and converse fluently in both Malay and Dusun languages. 
Exclusion criteria:

- Patients with acute medical or psychiatric illnesses (e.g. acutely in intoxication or withdrawal from alcohol, or acute liver failure).

- Using any other psychotropic medications.

- Any comorbid neurocognitive disorders that would affect their ability to answer the questionnaires.

Full written consent was obtained from fifty individuals who met the selection criteria to participate in the study. The study participants completed five separate questionnaires: a simple demographic questionnaire, the Dusun (AUDIT-D) and the Malay (AUDIT-M) versions of AUDIT, the validated Malay version of the alcohol dependence subscale of the Mini-International Neuropsychiatric Interview (M.I.N.I.), and the validated Malay version of the CAGE Assessment for Alcohol Abuse (CAGE). English versions were not used as the level of English fluency in the villages concerned was low.

A brief questionnaire was used to record some relevant background information including age and gender. Due to the inclusion criteria imposed of Dusun language fluency and current alcohol use, all participants were of the same ethnicity, citizenship, and religion. Participants were instructed to complete the questionnaires by filling in the blanks and selecting one response that best described them.

The mini international neuropsychiatric interview (M.I.N.I.), version 6.0.0

The M.I.N.I. is a short structured diagnostic interview designed to obtain DSM-IVTR lifetime and current diagnoses covering 10 psychiatric disorders [15]. The M.I.N.I. has good validity and reliability, and can be administered in a short period of time, and the M.I.N.I 6.0 is the latest one to have been fully validated into Malay. This Alcohol Dependence subscale of the instrument was used to confirm alcohol dependence among the participants. It was also used as the gold standard diagnostic instrument in calculating optimal cut-off points for the AUDIT-D.

\section{CAGE assessment for alcohol abuse (CAGE)}

The CAGE is a screening instrument for the detection of alcoholism. It consists of only four easy to understand items and takes less than $1 \mathrm{~min}$ to complete. Two or more affirmative responses suggest that the patient has a drinking problem $[16,17]$.

All analyses were conducted using the Statistical Package for the Social Sciences version 21.0 (SPSS, Chicago, IL). To determine optimal cut-off points for the AUDIT-D in the current population in the validation study, signal detection theory methods were employed. Receiver operating characteristics (ROC) curves were plotted, with the area under the curve (AUC) calculated for all values with sensitivity and specificity. The gold standard tool used was the M.I.N.I. alcohol dependence subscale. Youden's J index was also calculated for all values to ensure that the point with maximal sensitivity and specificity was identified through numerical rather than pure visual inspection methods.

In order to examine if the factor structure of the AUDIT-D was similar to that of the previous AUDIT-M, an exploratory factor analysis was done. Principal component analysis with direct oblimin rotation was done to explore the factor structure of the AUDITD. Cronbach's alpha was used to assess the internal consistency of AUDIT-D and its

Pang, Lee, Tseu, Joss, Honey, Shoesmith, James, Loo, Lasimbang 
Table 1. Socio-demographic characteristics of participants

\begin{tabular}{|c|c|c|c|}
\hline Variables & & $\mathrm{N}=50$ & Percent $(\%)$ \\
\hline \multicolumn{4}{|l|}{ Gender } \\
\hline Male & & 25 & 50 \\
\hline Female & & 25 & 50 \\
\hline Variable & Mean & Median & Mode \\
\hline Age & 30.3 & 21 & 21 \\
\hline
\end{tabular}

subscales. The Spearman correlation was used to assess the relationship between AUDIT-D and the AUDIT-M, CAGE, and the alcohol dependence subscale of the M.I.N.I.

Permission to conduct the research project was obtained from the Medical Ethics Committee of Universiti Malaysia Sabah. There was no conflict of interest or sponsorship from pharmaceutical companies. Funding to perform the research was given via a University Health Promotion sponsorship of RM2,500 for 17 medical and nursing students involved in the data collection.

\section{Results}

Table 1 shows the results of the descriptive statistics. A total of 50 participants were enrolled. The mean age was 30.3 while there was an equal distribution of males and females (25 each). Skewness and kurtosis for age was $<2.00$ suggesting a normal distribution.

All of them were the same race (Dusun) and the same religion (Christian). In terms of education levels, $100 \%$ of the respondents had completed secondary education, and there were no respondents that had completed university education.

\section{ROC Curve to Determine Cut-off Points in} Current Population

ROC curves were plotted from each AUDIT-D score as per Figure 1, and the AUC was calculated. AUC, sensitivity, specificity, and cut-off points for the AUDIT-D are presented in Table 2.

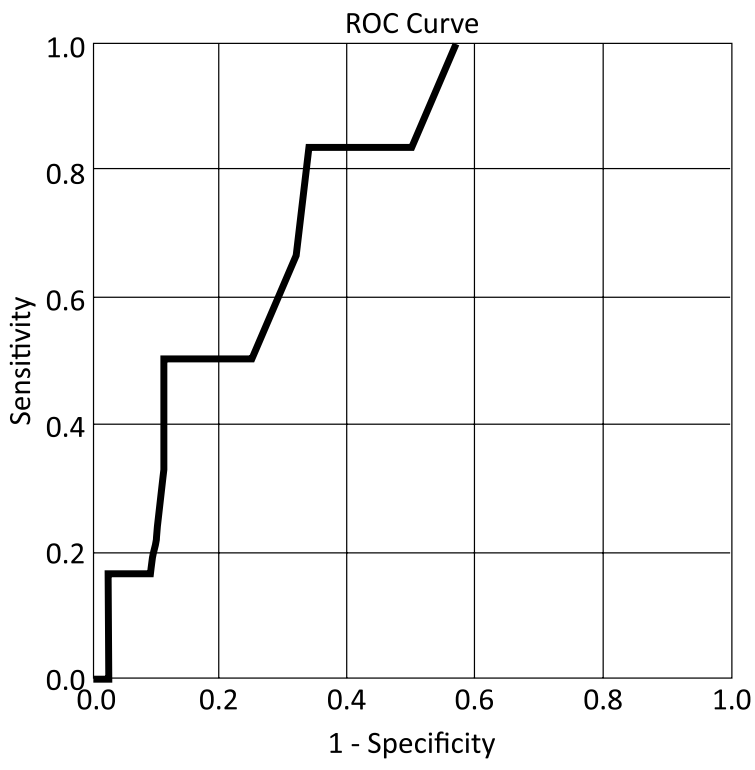

Figure 1. ROC curve for AUDIT-D scores 
Table 2. AUC, sensitivity, specificity, and cut-off points for AUDIT-D

\begin{tabular}{lc}
\hline 10-item AUDIT-D (Dependence screening) & \\
\hline AUC & 0.769 \\
SE & 0.084 \\
$95 \%$ CI & $0.604-0.934$ \\
Cut-off point & $\geq 9$ \\
Sensitivity & 0.833 \\
Specificity & 0.659 \\
Youden's J-index & 0.492 \\
\hline
\end{tabular}

For dependence, the results suggest optimal cut-off point for AUDIT-D as $\geq 9$ for dependence. This has a sensitivity of 0.833 and a specificity of 0.659 , with an AUC of 0.769. Using Youden's J-index, the point with the highest score was also $\geq 9$ (Youden's in$\mathrm{dex}=.492)$. Hence, using the calculated cutoff point, this yields 23 people screening positive for dependence in AUDIT-D (46\%).

\section{Factor Analysis}

Table 4 shows the results of the factor analysis. The Barlett's test of sphericity was significant $(\mathrm{p}<0.001)$ and the Kaiser-MayerOlkin measure of sampling adequacy for the AUDIT-M was 0.795 indicating acceptable sampling [19]. Principal component analysis produced three factors $>1.000$ when examining the eigenvalues. However, the second and third factor in the model both only had eigenvalues barely exceeding 1.000 .

When examining the scree plot in Figure 2 , either a one-factor or a three-factor model seems to be suitable. A one-factor model explained $43.58 \%$ of the variance, whereas a three-factor model explained $69.71 \%$ of the variance. Hence correlation matrices for both one- and three-factor solutions were examined.

When a three-factor solution was used, after excluding all factors with coefficients of 0.3 and below, the three factors clustered as per Table 4 above. The first factor, accounting for $43.578 \%$ of the variance, consisted of Questions 1-6 and Question 8. The correlations were all $>0.617$ and the Cronbach alpha for the first factor was 0.870 . The second factor consisted of Question 7 on its own, with

Table 3. AUDIT risk category using AUDIT-D cut off points

\begin{tabular}{lcc}
\hline AUDIT risk category & Number & Percentage \\
\hline Not dependent $(<9)$ & 27 & $54 \%$ \\
Dependent $(9$ and above) & 23 & $46 \%$ \\
\hline
\end{tabular}


Table 4. Principal axis factor structure of AUDIT-D (three factors)

\begin{tabular}{|c|c|c|c|}
\hline \multirow[t]{2}{*}{ Questions for AUDIT-D } & \multicolumn{3}{|c|}{ Factors } \\
\hline & $\begin{array}{l}\text { Individual } \\
\text { use }\end{array}$ & Guilt & $\begin{array}{l}\text { Impact on } \\
\text { others }\end{array}$ \\
\hline $\begin{array}{l}\text { 1. How often do you have a drink containing alco- } \\
\text { hol? }\end{array}$ & 0.870 & & \\
\hline $\begin{array}{l}\text { 4. How often during last year have you found that } \\
\text { you were not able to stop drinking once you had } \\
\text { started? }\end{array}$ & 0.819 & & \\
\hline $\begin{array}{l}\text { 6. How often during last year have you needed a } \\
\text { first drink in the morning to get yourself going } \\
\text { after a heavy drinking session? }\end{array}$ & 0.809 & & \\
\hline $\begin{array}{l}\text { 3. How often do you have six or more drinks on } \\
\text { one occasion? }\end{array}$ & 0.733 & & \\
\hline $\begin{array}{l}\text { 5. How often during last year have you failed to do } \\
\text { what was normally expected from you because } \\
\text { of drinking? }\end{array}$ & 0.694 & & 0.339 \\
\hline $\begin{array}{l}\text { 8. How often during the last year have you been un- } \\
\text { able to remember what happened the night be- } \\
\text { fore because you had been drinking? }\end{array}$ & 0.665 & 0.476 & \\
\hline $\begin{array}{l}\text { 2. How many drinks containing alcohol do you } \\
\text { have on a typical day when you are drinking? }\end{array}$ & 0.617 & -0.414 & -0.385 \\
\hline $\begin{array}{l}\text { 7. How often during the last year you had a feeling } \\
\text { of guilt or remorse after drinking? }\end{array}$ & & 0.862 & \\
\hline $\begin{array}{l}\text { 9. Have you or someone else been injured as a result } \\
\text { of your drinking? }\end{array}$ & 0.399 & & 0.721 \\
\hline $\begin{array}{l}\text { 10. Has a relative or friend or a doctor or another } \\
\text { health worker been concerned about your drink- } \\
\text { ing or suggested you cut down? }\end{array}$ & 0.443 & & 0.673 \\
\hline Cronbach alpha & 0.870 & - & -0.243 \\
\hline Eigen value & 4.358 & 1.365 & 1.248 \\
\hline Total variance explained & 43.578 & 13.649 & 12.482 \\
\hline
\end{tabular}

a correlation of 0.862 . The third factor consisted of Questions 9-10, with correlations $>0.673$, however with a Cronbach alpha of $-0.243$
Subsequently, when looking at a one-factor solution only as per Table 5, Question 7 ("guilt about drinking alcohol") only had correlation $<0.300$ so it was excluded from a 


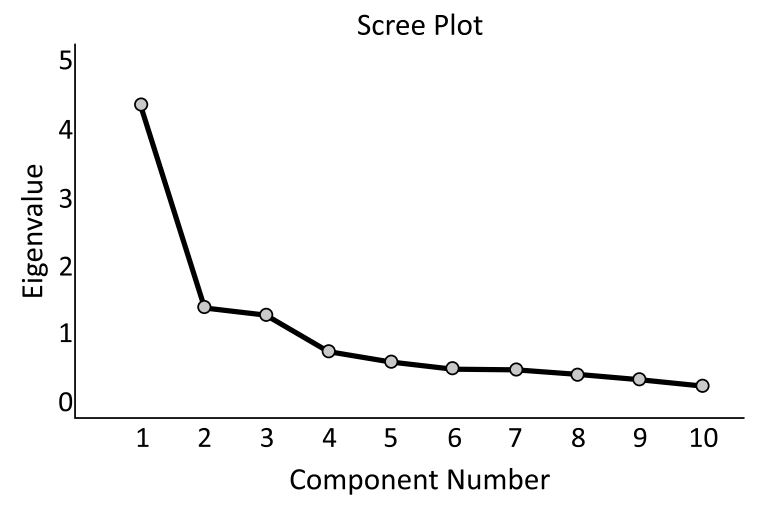

Figure 2. Scree Plot for Factor Analysis of AUDIT-D one-factor model entirely. The other 9 questions all remained significant with correlation $>0.300$ within a one-factor model. However, just as with a three-factor model, there were fairly strong correlations between Questions 1-6 and 8 with correlations $>0.647$, while Question 9-10 merely correlated weakly with the other 7 (0.399-0.443) despite still fitting into a one-factor model.

\section{Correlations}

Cronbach alpha of the entire AUDIT$\mathrm{D}$ was 0.826 which suggests good internal

Table 5. Principal axis factor structure of AUDIT-D (one factor)

\begin{tabular}{|c|c|}
\hline Questions for AUDIT-D & Single Factor \\
\hline 1. How often do you have a drink containing alcohol? & 0.870 \\
\hline $\begin{array}{l}\text { 4. How often during last year have you found that you were not able } \\
\text { to stop drinking once you had started? }\end{array}$ & 0.819 \\
\hline $\begin{array}{l}\text { 6. How often during last year have you needed a first drink in the } \\
\text { morning to get yourself going after a heavy drinking session? }\end{array}$ & 0.809 \\
\hline 3. How often do you have six or more drinks on one occasion? & 0.733 \\
\hline $\begin{array}{l}\text { 5. How often during last year have you failed to do what was normally } \\
\text { expected from you because of drinking? }\end{array}$ & 0.694 \\
\hline $\begin{array}{l}\text { 8. How often during the last year have you been unable to remember } \\
\text { what happened the night before because you had been drinking? }\end{array}$ & 0.665 \\
\hline $\begin{array}{l}\text { 2. How many drinks containing alcohol do you have on a typical day } \\
\text { when you are drinking? }\end{array}$ & 0.617 \\
\hline $\begin{array}{l}\text { 10. Has a relative or friend or a doctor or another health worker been } \\
\text { concerned about your drinking or suggested you cut down? }\end{array}$ & 0.443 \\
\hline $\begin{array}{l}\text { 9. Have you or someone else been injured as a result of your drink- } \\
\text { ing? }\end{array}$ & 0.399 \\
\hline $\begin{array}{l}\text { 7. How often during the last year you had a feeling of guilt or remorse } \\
\text { after drinking? }\end{array}$ & - (below 0.300) \\
\hline Cronbach alpha & 0.826 \\
\hline Eigen value & 4.358 \\
\hline Total variance explained & 43.578 \\
\hline
\end{tabular}


Table 6. Spearman's correlation between scales (rho)

\begin{tabular}{lcccc}
\hline & & & MINI & \\
& AUDIT-D & AUDIT-M & (dependence) & CAGE \\
\hline AUDIT-D & - & $0.999^{* *}$ & $0.624^{* *}$ & 0.390 \\
AUDIT-M & - & - & $0.617 * *$ & 0.379 \\
M.I.N.I. (dependence) & - & - & - & 0.322 \\
\hline
\end{tabular}

$* *: p<0.001$

consistency. The reliability coefficient for the AUDIT-D and AUDIT-M version was rho $=0.999(p<.0001)$ which shows high reliability.

\section{Concurrent validity}

Table 6 shows the Spearman's correlations between the AUDIT-D and the participants' scores on the AUDIT-M, CAGE, and MINI alcohol dependence subscale. The AUDIT$\mathrm{D}$ was positively correlated with AUDIT-M (rho=0.999, $\mathrm{p}<0.0001$ ) and the MINI (alcohol dependence subscale) scores ( $\mathrm{rho}=0.624$, $\mathrm{p}<0.0001)$ which suggests good concurrent validity. AUDIT-M was also correlated with MINI (dependence) scale (rho $=0.617$, $\mathrm{p}<0.0001)$. There were no significant correlations with the CAGE questionnaire with all 3 other research instruments measured.

\section{Discussion}

This study suggests the AUDIT-D has valid psychometric properties that make it a reliable and valid instrument in screening for alcohol use disorders amongst the Dusun language speaking population. This conclusion is founded upon a solid methodology, i.e. bidirectional translations and back translations by both language and content experts, harmonisation and pilot testing, and relevant statistical analyses upon a statistically significant number of respondents. This study also yielded a cut-off point for dependence using ROC curve analysis which was lower than that of the original English scale [1]. This is consistent with other studies round the world that usually suggest that cut-off points shift when the AUDIT is validated into different languages $[4,5,20]$. This may be a mixture of differing cultural sensitivities, cultural mores and values about alcohol, and different interplays between tradition and alcohol.

Interestingly, this study demonstrated either a one- or three-factor model for the AUDIT-D. This differs from the two-factor model suggested by the AUDIT-M validation [5]. This correlates with systematic reviews on the factor structure of the AUDIT, which suggests that one- or two-factor structures depend on whether alcohol dependence prevalence rates are high or low [20]. In high prevalence societies, the factor structure tends to have one factor; in lower prevalence societies, factors tend to congregate just like in the AUDIT-M, into two factors i.e. "consumption" and "alcohol related problems" or adverse consequences of drinking alcohol, similar to other studies [1]. 
There could be multiple other reasons for this divergent factor structure. AUDIT-D was performed in a culturally homogenous and distinct population compared to the AUDIT-M, which was performed in a culturally heterogenous West Malaysian population [5]. Naturally, the population validating an AUDIT-D would be ethnically homogenous, as one of the inclusion criteria is fluency in Dusun, a native language that is only spoken by members of the tribe concerned. The demographics of alcohol use in West Malaysia is significantly different, as it was introduced by British colonial masters for indentured Indian labourers, and thus has less associations with an indigenous cultural tradition [6]. In Sabah and Sarawakian Borneo on the other hand, it is more interlinked with tradition and culture [10]. There is a huge role for alcohol for home brewing for festivities and connotations of pleasure, togetherness and enjoyment [22]. Hence there might be much less connotation of "guilt" and "concern from another person about drinking" in Sabahan Borneo. This is reflected in the factor analysis outcome that classified "guilt" and "concern from others" as separate factors in the Sabahan context.

Inferring from this, alcohol has a complex role in traditional communities in the Sabahan context. Alongside the perceived social benefits in the literature, alcohol causes untold damage socially, medically, and occupationally in Sabah [7]. It contributes to alcoholrelated harm including domestic violence, motor vehicle accidents, and physical altercations [10]. It also increases the burden of care to both medical and psychiatric hospitals in Sabah; it is estimated that $23.6 \%$ of alcohol consumption in Sabah falls in the "risky" category [23]. This compares with 46\% depen-

Archives of Psychiatry Research 2020;56:129-142 dence in the current study, using the AUDITD cut-off points from the ROC curve.

This thus represents a vital finding to explore qualitatively in future studies. The factor structure of the Bornean ethnic language AUDIT is significantly different from the West Malaysian (Malay) one, suggesting possible integral cultural differences between West and East (Bornean) Malaysia are present in terms of perceptions of alcohol drinking attitudes and behaviours, despite ostensibly being in the same country. This has potential implications on current healthcare alcohol policies in East Malaysia. Currently, there are already locally sensitive, culturally aware alcohol prevention modules that are delivered by peers and members of the local community as a manualised "alcohol toolkit for peer support workers". This is currently available in the Malay language but with local Kadazandusun peer support deliverers [7]. It is hoped that availability of an AUDIT-D will be a crucial further step in fully ethnicising the alcohol toolkit, allowing it to account for the differing perceptions of West and Bornean Malaysia about drinking.

As the correlation between AUDIT-D and AUDIT-M was 0.999 with statistical significance, it can be surmised that the factor structure for AUDIT-M (in Borneo specifically) would be different as well from the West Malaysian one. More studies should be performed in wider catchment areas (as this was merely a validation study), focusing on clarifying the factor structure of the AUDIT$\mathrm{M}$ in other Bornean ethnic cultures.

\section{Conclusion}

The study findings confirm that the AUDIT-D is a psychometrically sound instrument with good internal consistency and con-

Pang, Lee, Tseu, Joss, Honey, Shoesmith, James, Loo, Lasimbang 
current validity. The study also determines a new optimal cut-off point for the AUDIT in the Bornean population. Hence it is a sound instrument for assessing and detecting alcohol abuse in Sabahan Borneo. Further efforts need to be done in terms of qualitative studies to explore the differences in drinking psychology, culture, perception of risk or harm, and socioeconomic stigma in Bornean Sabah, as this has huge implications on healthcare policy with regards alcohol prevention in Borneo. This study also represents a "giant leap forward" for ethnic sensitivity in alcohol and mental health research in Sabah, as it is

\section{References}

1. Saunders JB, Aasland OG, Babor TF, la Fuente JR, Grant M. Development of the alcohol use disorders identification test (AUDIT): WHO collaborative project on early detection of persons with harmful alcohol consumption-II. Addiction. 1993;88:791-804.

2. MacKenzie DM, Langa A, Brown TM. Identifying hazardous or harmful alcohol use in medical admissions: a comparison of audit, cage and brief mast. Alcohol Alcohol. 1996;31:591-9.

3. Malet L, Schwan R, Boussiron D, Aublet-Cuvelier B, Llorca P-M. Validity of the CAG questionnaire in hospital. Eur Psychiatry. 2005;20:484-9.

4. Pradhan B, Chappuis F, Baral D, Karki P, Rijal $\mathrm{S}$, Hadengue $\mathrm{A}$, et al. The alcohol use disorders identification test (AUDIT): validation of a Nepali version for the detection of alcohol use disorders and hazardous drinking in medical settings. Subs Abuse Treat Prev Policy. 2012;7:42.

5. Yee A, Adlan ASA, Rashid RR, Habil H, Kamali K. Validation of the alcohol use disorders identification test (AUDIT) - Bahasa Malaysia version among a group of alcohol users. J Subst Use. 2015;20:229-33.

6. Jernigan DH, Indran SK. Country profile on alcohol in Malaysia. Alcohol Publ Health. 1999;8:61-73. the first ever instrument to be translated into a local language. This will break down walls of stigma, increase uptake rates of screening, detection, and intervention, and hopefully reduce the divide between healthcare services and the common man in ethnic Sabahan Borneo.

\section{Acknowledgements}

None.

\section{Conflicts of interest}

None to declare.

7. Lasimbang HB, Eckermann E, Shoesmith WD, James S, bin Igau AE, Iggau O, et al. Alcohol Toolkit Empowering Sabah Indigenous Communities to Reduce Alcohol Related Harm. Borneo J Med Sci. 2019;13:11-8.

8. Tha NO, Shoesmith W, Naing KS, Abbas RBH, Abdullah AF, JJ. RN. Alcohol Related Attitudes and Drinking Behaviors in Rural Sabah. Proceedings of 3rd ICORM (International Conference on Rural Medicine). 2011.

9. Institute for Public Health, National Institutes of Health, Ministry of Health Malaysia. National Health and Morbidity Survey 2011. [Internet] 2011. [Cited October 17th 2019] Available from: http:/ / www.iku.gov.my/images/IKU/Document/REPORT/NHMS2011-VolumeII.pdf

10. Lasimbang HB, Shoesmith W, Nazri M, Mohd B, Kaur N, Chin M, et al. Private troubles to public issue : empowering communities to reduce alcoholrelated harm in Sabah, Malaysia. Health Prom Int. 2015;1-8.

11. Ethnologue. Central Dusun [Internet]. 2015 [Cited October 17th 2019 ]. Available from: https:// www.ethnologue.com/18/language/dtp/

12. Schotanus-Dijkstra M, Ten Have M, Lamers SMA, de Graaf R, Bohlmeijer ET. The longitudinal relationship between flourishing mental health and in- 
cident mood, anxiety and substance use disorders. Eur J Public Health. 2016;27:563-8.

13. Institute for Public Health, National Institutes of Health, Ministry of Health Malaysia. National Health and Morbidity Survey 2015. [Internet] 2015. [Cited October 17th 2019] Available from: http://www.moh.gov.my/moh/resources/nhmsreport2015vol2.pdf

14. WHO. Management of substance abuse. [Internet]. Process of translation and adaptation of instruments. [Internet] 2018 [cited January 1st 2019]. Available from: http://www.who.int/substance_ abuse/research_tools/translation/en/

15. Sheehan D V, Lecrubier Y. The mini international neuropsychiatric interview version 6.0 (MINI 6.0). Jacksonville, USA: Med Outcomes Syst Inc.; 2010.

16. Ewing JA. Detecting alcoholism: the CAGE questionnaire. Jama. 1984;252:1905-7.

17. Dhalla S, Kopec JA. The CAGE questionnaire for alcohol misuse: a review of reliability and validity studies. Clin Investig Med. 2007;30:33-41.

18. Division. FH. Prosiding Mesyuarat Membincangkan Hasil Kajian Saringan dan Pengendalian Masalah Autisme. [Internet] 2006 [Cited October 17th 2019] Available from: http://webcatplus.nii. ac.jp/webcatplus/details/book/25790791.html

19. Pett MA, Lackey NR, Sullivan JJ. Making sense of factor analysis: The use of factor analysis for instrument development in health care research. Thousand Oaks, USA: Sage Publications, Inc.; 2003.

20. de Meneses-Gaya C, Zuardi AW, Loureiro SR, Crippa JAS. Alcohol Use Disorders Identification Test (AUDIT): An updated systematic review of psychometric properties. Psychol Neurosci. 2009;2:83-97.

21. Kelly TM, Donovan JE. Confirmatory factor analyses of the alcohol use disorders identification test (AUDIT) among adolescents treated in emergency departments. J Stud Alcohol. 2001;62:838-42.

22. Heath DB. International handbook on alcohol and culture. Westport, USA: Greenwood Publishing Group, Inc.; 1995.

23. Mutalip MH, Kamarudin RB, Manickam M, Abd Hamid HA, Saari RB. Alcohol consumption and risky drinking patterns in Malaysia: findings from NHMS 2011. Alcohol Alcohol. 2014;49:593-9.

\section{Potvrđivanje učinkovitosti testa identifikacije poremećaja uzrokovanih alkoholom (AUDIT) - verzija na Dusun jeziku u konzumenata alkohola u Sabahu, Borneo}

Sažetak - Uvod: Test identifikacije poremećaja uzrokovanih alkoholom (AUDIT eng. The Alcohol Use Disorder Identification Test) kojeg je razvila Svjetska zdravstvena organizacija (WHO), od iznimne je koristi u identifikaciji pojedinaca koji boluju od poremećaja ponašanja uzrokovanih alkoholom. Doduše, ne postoji kulturološki primjerena verzija testa na Dusun jeziku u saveznoj državi Sabah na otoku Borneu, Malezija. Cilj ovog istraživanja je razviti i potvrditi verziju AUDIT test na Dusun jeziku. Metode: AUDIT test je preveden na Dusun jezik, zatim s Dusun jezika na engleski i malezijski. Prva verzija je bila pilot test koji je uključio 20 ispitanika, te je bio usklađen. Usklađena verzija testa je provedena na 50 ispitanika čiji je prvi jezik bio Dusun, te su također bili tečni u malezijskom jeziku, a bili su žitelji ruralnih sela Sabaha. Ispitanici su ispunili socio-demografske upitnike, Dusun (AUDIT-D) i Bahasa malezijske (AUDIT-M) verzije testa, usklađene verzije M.I.N.I. testa alkoholne ovisnosti na Bahasa malezijskom jeziku, te CAGE upitnik. Rezultati: ROC krivulje izračunale su graničnu ovisnost AUDIT-D od 9 i više, s prevalencijom ovisnosti od 46\%. Faktorska analiza AUDIT-D dala je jedno- ili trofaktorsko rješenje, za razliku od strukture faktora u AUDIT-M testu. Cronbach alfa koeficijenti 
za ukupni AUDIT-D bili su 0,83. Značajne Spearmanove korelacije postojale su između AUDIT-D i AUDIT-M rezultata (Spearmanov rho $=0,999, p<0,001$ ). AUDIT-D i AUDIT-M bili su značajno povezani s M.I.N.I. podskupinama za ovisnosti o alkoholu ( $r h o=0,624$ i 0,617, s $p<0,0001$ ). Oba nisu pokazala značajnu povezanost s CAGE upitnikom. Zaključak: AUDIT-D upitnik ima prihvatljiva psihometrijska svojstva i pokazuje slične faktorske strukture u odnosu na druga područja s visokom prevalencijom ovisnosti o alkoholu. Prikladan je za procjenu i utvrđivanje poremećaja ponašanja uzrokovanih konzumacijom alkohola u jedinstvenom kulturnom krajoliku Sabaha.

Ključne riječi: AUDIT, alkohol, Dusun, M.I.N.I. 
